\title{
Teaching English as a foreign language to young
}

\section{adolescents}

\section{La enseñanza del inglés como idioma extranjero en jóvenes adolescentes}

Silvia Elizabeth Cárdenas Sánchez. ${ }^{1}$, Lina Yolanda Morales Rodas. ${ }^{2}$ \& Andrea Paola Goyes Robalino. ${ }^{3}$

\begin{abstract}
.
DOI: https://doi.org/10.33262/cienciadigital.v3i3.1.678

Ecuadorian education is framed in public, Fiscomisional and private education which allows students to choose the educational institution according to their needs and facilities. Education has been a state policy that has taken more impetus in recent years and has been emphasized in the increase of hours in English. From elementary school to high school, students attend English classes framed in the development of language skills. Similarly, within the laws and regulations in the educational framework the student is considered as a being with individual needs and differences. For this reason, the following work presents all the considerations that an English teacher should consider when working with students who are going through the stages of intellectual, physical, moral, emotional and social development. Furthermore, different suggestions are presented that are applicable within the classroom based on applied research studies in similar contexts.
\end{abstract}

Keywords: EFL, Student's Development, Language Standards.

1 Escuela Superior Politécnica de Chimborazo, Sede Morona Santiago, Macas, Ecuador. silvia.cardenas@espoch.edu.ec

2 Escuela Superior Politécnica de Chimborazo, Sede Morona Santiago, Macas, Ecuador. lina.morales@espoch.edu.ec

3 Escuela Superior Politécnica de Chimborazo, Sede Morona Santiago, Macas, Ecuador. andrea.goyes@espoch.edu.ec 


\section{Resumen.}

La educación ecuatoriana está enmarcada en el ámbito particular, fiscomisional y público lo cual permite que los estudiantes puedan elegir la institución educativa de acuerdo con sus necesidades y facilidades. La educación ha sido una política de estado que ha tomado mayor impulso en los últimos años y se ha enfatizado en el incremento de horas en la asignatura de inglés. Desde la educación básica hasta el bachillerato, los estudiantes toman clases del idioma extranjero enmarcado en el desarrollo de las destrezas del idioma. De igual manera, dentro de las leyes y reglamentos en el marco educativo se considera al estudiante como un ser con necesidades individuales considerando su desarrollo en todas sus etapas. Por tal motivo, el siguiente trabajo presenta todas las consideraciones que un docente de inglés debe tener en cuenta en el momento de trabajar con estudiantes cuando a la vez están atravesando las etapas del desarrollo intelectual, físico, moral, emocional y social. Además, se presenta sugerencias que son aplicables dentro del aula en base a estudios de investigación aplicados en similares contextos.

Palabras claves: EFL, Desarrollo Estudiantes, Estándares De Los Idiomas.

\section{Introduction.}

Teaching children, adolescents and adults is one of the main concerns in many countries. Educating people means to fulfill their necessities to build a better future. As in many other countries, Ecuador is also improving every day its educational system. Ecuadorian educational system is organized in General Basic Education (GBE), high school and College education. General Basic Education is mandatory and it is considered from the first year to the tenth year. Students who have finished the General Basic Education must study three years more at high school in order to get a diploma. Many of them keep studying college to get a degree in different specializations. First of all, students get to high school with different backgrounds, thoughts, and questions from primary school. For instance, when students are in elementary school, they have more teacher and parents' commitment. On the other side, students who start eighth grade have to face more challenges, as parents and teachers' support is not enough as it was when they were in primary school.

Ecuadorian educational system has improved. There have been many changes to encourage learners and teachers to think creatively and become more aware of their personal growth through education. First, studying basic education from first to eighth grade is mandatory. Students' materials are free for public education. These new improvements have encouraged adolescents to finish high school in order to look for new opportunities, which would increase if learners decide to study and specialize at the University.

Nowadays, there are also a higher percentage of students in the classrooms than before. Adolescents are aware of the great opportunity they have to study free, and they make efforts to get a high school degree. Ecuadorian education system needs many changes to improve 
and take it to a whole new level; promoting teachers training is one of the main purpose of the government.

Indeed, it is worth mentioning that one of the most important aspects that has changed in Ecuadorian educational system is the curriculum design. At first, it was difficult to introduce it, but the acceptance has been increasing. Ecuadorian private, public and semi-public institutions have the same objectives planned in every curriculum. English is one of the subjects that is taught and considered in most of the institutions as a foreign language in their curriculum since the first year of GBE. English curriculum is designed according to international standards and it is a mandatory subject for students from 8th year of GBE and they must achieve certain English skills according to the grade level. Moreover, students have to reach B2 level to get a college diploma. As English has been acquired a high consideration and importance in Ecuadorian educational system, teachers need to improve their knowledge, attending courses as they have the responsibility to teach English properly to help students to achieve their curriculum goals. In order to do that, they have to develop dynamic lesson plans and think about new strategies and innovative techniques.

According to Ecuadorian In-Service English teacher standards (2012), English teachers have to "comprehend and apply knowledge of socio-cultural, psychological, and political variables to facilitate the process of learning English" (p. 3). Indeed, the process of learning English includes different cultural and family backgrounds that could affect their schooling. According to Queen (2002), students can face two kind of transitions. The first one is the structure of the school system and another one is developmental. Related to what mentioned previously, it is necessary to analyze each aspect of adolescents' development to be aware of the importance of knowing students.

\section{Literature Review}

\section{Characteristics of young adolescents}

Brown and Knowles (2007) say that, teenagers' stage is a "period of time characterized by vast developmental changes" (p. 3), which means that young adolescents are people who are growing and facing many challenges that vary in each personal experience. Teenagers look for independence and their thoughts are opposite to the adults' one. They aim to be part of the society individually and leave apart the safety their parents have been assuring them in order to face life and know new people. The authors also state that the main responsibility of the teachers is to learn about student's life changes and be prepared and aware of each personal situation to help young adolescents to be successful at school. Specifically, Crawford (2008) affirms that, "adolescence is a developmental time of erratic physical growth, social exploration, and unfolding intellectual capacity. It is a time to awakening, 
realization, anticipation, confusion, awkwardness, transition, change, identify defining, and self-discovery" (p. 26).

Additionally, Lerner (2002) claims that adolescence is a period of transition, dramatic changes, excitement and anxiety. Also, the author argues that "adolescence is a confusing time for the adolescent experiencing this phase of life, for the parents who are maturing the adolescent during his or her progression through this period, and for the other adults charged with enhancing the development of youth during this period, such as teachers, coaches, and so on" (p. 5).

On one side, developmental learning needs to construct meaningful concepts, which are also necessary to take in consideration to teach adolescents. That's why Crawford (2008) describes these learning needs as personal connections because they have to connect personal experiences with the new knowledge.

On the other side, intellectual challenges and metacognitive developments are also necessary because teenagers are developing their cognitive capacities during their learning process. It is no less important talking about emotional engagement as it is essential to keep students motivated. Finally, social interaction and comfortable learning environment help them to support their education.

\section{Physical development}

According to Brown and Knowles (2007), adolescents should understand if the physical development they are experiencing is positive or negative. For this reason, they need some guidance in order to have an answer to their concerns about it. As teenagers, they are up to be active and curious so that teachers have to take into consideration different activities to do indoor or outdoor, which should be part of their lesson plan. In some occasions, occurs that students of this age, could be restless and without energies. That's why breaks and sneaks are essential to keep students focused on the topic.

In addition, physical activity is very important for teenagers' growth. Sund, Larsson, and Wichstrom (2011) conducted a study to know if physical or sedentary activities are factors to develop depressive symptoms in adolescents. The results of this study showed that actually sedentary or low level physical activities were risk factors for adolescents to get into depressive symptoms.

On the other hand, Brown and Knowles (2007) assert that adolescents are worried about their body image. Depending on personal physical developments, some people show signs of adult features like muscles, voice in boys, and other characteristics of this age earlier than others. As a consequence, according to Williams and Currie (2000), self-esteem, pubertal timing, and body image are connected and as demonstrated self-esteem is low in the pubertal timing because some teenagers experience a late maturation. 
Adolescents are concerned with their body size and perceived appearance. Moreover, Dorn, Susman, and Ponirakis (2003) conducted a study to analyze if the pubertal timing is in relation with adjustment and behavior problem, based on data collected from a group of 52 girls from 9 to 14 years old and 56 boys from 10 to 15 years old. The results indicated that both men and women who had late maturing present more social adjustments and behavioral problems. While, adolescents with an earlier maturation did not suffer those kind of problems.

Lerner (2002) suggests that physical and physiological changes cause alterations in adolescents' body. The adolescents are going to pass though the pre-pubescence till the pubescence. Pre-pubescence is characterized by the first signs of sexual maturations; while, in the pubescence the growth spurt occurs. The adolescents experiment changes like weigh, height, or breast. Also, in women start the menstruation period and this can bring some problems like dysmenorrhea or amenorrhea. Some experts claim that at this age eating disorders may appear since teenagers are worried about their body image. These disorders as anorexia or bulimia are more common in women than in men.

Based on theoretical framework, it can be said that physical changes in adolescent are linked with behavioral problems. According to relevant studies, there are many physical issues to keep in mind when students are in the young adolescence. Some of them state that physical growth and self-esteem are connected.

\section{Intellectual development}

Brown and Knowles (2007) argue that young adolescents are changing from the concrete to the formal operational thought. This will include solving abstract problems developing their critical thinking skills and metacognition. Furthermore, Lerner (2002) affirms that cognitive developments should be represented by quantitative and qualitative characteristics. Students who get better scores in abstract subjects have been improving their critical thinking skills. The author states also that "during adolescence, thought changes from being predominantly concrete to being predominantly abstract" (p. 94). Another important fact is adolescents' egocentrism. In fact, teenagers have the perception that people focus their attention on their appearance rather than their knowledge and psychologically they distort the reality around them and assume wrong and negative thoughts.

As a consequence, teachers have the responsibility to understand and pay attention to students' behavior and thoughts as they are living a delicate phase of their life and this can affect their academic achievement as Lerner (2002) finds in his research.

As a solution or suggestion to the mentioned situation, Crawford (2008) states that students need hands-on activities and authentic learning in order to develop abstract thinking by providing challenging activities. Teachers have to present different activities to help students 
to store the new concepts in the long-term memory. These activities can be used according to the topics and learning goals.

\section{Emotional development}

Santrock (2012) defines emotion as "feeling, or affect that occurs when a person is in a state or in an interaction that is important to the individual, especially to his or her well-being" ( $p$. 150). When adolescents are developing their emotions, they can make wrong decision, because they find self-regulation of their emotions difficult to control. Indeed, at this age, they are looking for peer acceptance. King, Lengua, and Monahan (2013) state that

"Although children's ability to regulate their behaviors continues to improve throughout childhoods and adolescence, it remains unclear how contextual risk factors might influence this development during the transition to adolescence or how variation in the development of self-regulation predicts adjustment" (p. 57).

Then, according to Lerner (2002) "if an adolescent cannot find a role that resolves the emotional upheaval which results from the sting societal and personal mandates for role adoption, and identity crisis may result" (p.158). As a matter of fact, being accepted in a society is a common aim for many people at any age especially for teenagers. For that reason, Oberle, Sschonert-Reichl, and Thomson (2010) developed a study in which they demonstrated that empathy and optimism are important for girls' acceptance of peers while positive affect is not essential. On the other hand, positive affect predicted peer acceptance in boys and empathy or anxiety are not related with acceptance at all. The authors suggest including social and emotional comfort as a complement to peer acceptance.

Some adolescent want to discover their identity finding many conflicts at this age. With reference to Lerner (2002) investigation, self-regulation and identity would allow adolescents to reach their goals because they could explore the world and interact with society. It is important that people around adolescent guides them. With guidance, they could discover who they are and what they want for their future.

Santrock (2012) finds that adolescents express negative emotions to the others when they feel guilty or angry, which are considered a self-regulation competence. This kind of emotional state affect the social relationship they have with people of same age and causes conscience about the importance of not being overwhelmed by their own feelings. Moreover, the author explains there are other important factors that influence on them such as sexual experiences and romantic relationships that appears in the change to middle school. This life 
passage can cause stress and depression because of their hormone levels, which is very common in girls.

Crawford (2008) claims that, when students are learning, emotional engagement is important for them. They need to feel part of the group regardless their culture background, capabilities, or economic differences. Teachers have to create a comfortable environment where students can feel safe and engaged. The activities presented in the classroom should be authentic and exigent. As emotional experiences affect students' attention, motivation, intelligence and retention, problem-based learning is developed throughout games and simulations, class discussions, group works, interactive technology, projects development, and experiments (Crawford, 2008).

\section{Social Development}

Adolescent are looking for independence but at the same time they want to get involved more in social life. According to Lerner (2002), adolescents want to spend more time with their peers than with their parents. They want to be part of the crowd that they feel identified. At the beginning they try to get along with peers from the same sex. However, when they are in middle school, they look for a relationship. At this age, friendship is crucial. If friendship is engaged and stable, they will improve their self-esteem and will not do wrong decisions. But, if the friendship is not well-oriented, they will develop a disruptive behavior and the consequence can be deliquesced.

Crawford (2008) states that "adolescent learning is socially motivated through a natural inclination to interact with peers and a cognitive need to collaboratively construct knowledge and new language" (p. 34). Adolescents also need to develop social and personal skills. These skills can be developed by using cooperative learning strategies, literature circles, and other activities that involve interaction. Teachers have to consider ongoing assessment, instruction, and practice to help students to manage their group relationships (Crawford, 2008).

\section{Moral development}

According to Sylwestern (2007), morality and ethics are human being characteristics. Morality refers to issues related to the right or wrong decisions, possible and impossible goals, positive or negative behaviors, etc. When people have to follow certain behavioral codes means ethics development. Osguthore (2009) conducted a study to know about the relationship between a teacher's moral character and a student's moral development, concluding that teachers' moral character could not help to develop students' moral. 
In addition, Santrock (2012) suggests four domains for moral development, which are based on Hohlberg's levels. The first domain is pre-conventional reasoning in which moral thinking is connected with punishment. The other in which adolescents look for their own interest. Conventional reasoning is showed as a need to act in society considering its expectations. Finally, post-conventional reasoning appears when morality is internal. Then moral behavior is another domain. Adolescents follow models which must be reinforced positively. The moral behavior must be in concordance with the society rules. Moral feeling refers to empathy and conscience. Moral personality involves thoughts, behavior, and feelings.

\section{Area of concern}

Teaching in a middle school requires a deep understanding of students' development. As each individual is different, it is necessary to apply different strategies in order to teach the best way and to get better results accomplishing the varied difficulties they may have. For this reason, Crawford (2008) investigated that, students can reach their goals but they have different learning styles. Instructions should be based on students-centered and taking into account many factors such as emotional engagement, curriculum design, learning environment, students' needs, metacognition development, and social interaction. Learning environment influences adolescents' intellectual, social, physical, and emotional development. Moreover, Lerner (2002) states that "today, schools are in a state of crisis. They are charged by society with doing more than just educating youth but faced with diminishing resources and challenged by the complex of serious problems shown by the young people they encounter (p. 273).

Another factor to consider in education is that society also influences in students' achievement. However, the social context is very important because it helps adolescents to reach the academic goals. On the other hand, Lerner (2002) says that,
"Schools are training institutions, agents of cultural transmission, and as means to inculcate knowledge and values. Schools fulfill a maintenance- actualization role and are a place to develop optimal personal and interpersonal attributes and the ability to contribute to society" (p. 274).

Ecuadorian Institutions represent an opportunity for teenagers to grow in all the aspects as students spend most of their time there. Teachers have to provide many activities and have to adapt their methods according to students' development.

Ecuadorian In-Service English teacher standards (2012) argue, "The English Language Learning Standards (ELLS) tell us that students are expected to achieve a proficiency level in terms of knowledge and skills gained throughout the process" (p. 8). Moreover, these 
standards involve listening, writing, reading, and speaking language skills. Students have to reach level B2 at the end of the college.

According to what was mentioned, Teaching English in a middle level school requires special attention because students need authentic material and activities to reach the second language skills required. Becker (2001) suggests that, high school students who are learning English as a Second Language require a lot of hands-on classes like arts, physical education, or music, to interact in English between them. This interaction can help them feel more accepted and develop their cognitive and social skills.

In the same way Kingen (2000) explains that, becoming a middle level teacher entails a lot of commitment and energy, since middle level learners are very active. Moreover, Santrock (2012) informs about another kind of curriculum that is called "hidden curriculum". He states that "the hidden curriculum is conveyed by the moral atmosphere that is a part of every school" (p. 239). Teachers are considered like models for students and they can transmit positive or negative attitudes. Teachers must involve students in constructing their own knowledge, guiding them in order to have fewer difficulties in their transition to middle school. When they do not receive the correct guidance, problems like dropouts may occur. Moreover, classroom management is important when working with young adolescents, because adolescents are developing their social skills to interact in the classroom. Kingen (2000) argues, "A middle level teacher has to know when to put attention to distractions and when to ignore them, and how to distinguish honest criticism from hostile accusation." (p. 31).

\section{Conclusion}

- To sum up, teaching middle school learners requires a big commitment. Young adolescents are not only attending school to learn new concepts. They are attending school to experiment many changes while they are learning theories. It can be a difficult stage for many adolescents, but teachers' accountability will guide them in this process. Also, it is necessary teacher improvement and training to work with middle school learners. There is always something new to learn which helps students to improve their skills.

- Based on the theoretical framework, middle school students face age difficulties that is why they need more attention than a teacher can imagine, to overcome those situations. By applying new strategies that require hands-on activities could be one of the best options to keep student's motivation on learning. Specifically, it is considered that group work could be one of the best strategies to improve their social, moral and emotional development.

- Ecuadorian curriculum of teaching English as a second language is already designed. However, considering individual differences the curriculum should be adapted in order to take in account physical, emotional, moral, intellectual, and social changes. 
- When teachers talk about individual differences, they have to be aware of implications and promote new proper strategies to help each student.

- Teaching English young adolescents requires special attention to their backgrounds. Instructors have to apply different methods and techniques to construct knowledge with their students to reach the standards.

- Finally, teachers must keep all students motivated during classes. They are human beings that need to find out who they are and how to solve problems. They are vulnerable to choose the wrong way because they start to make important decisions by their own. Adults' guidance and commitment is important to help them to reach their goals and be prepared for the life.

\section{References.}

Brown, D. F., \& Knowles, T. (2007). What every middle school teacher should know. Portsmouth: Heinemann.

Crawford, G. B. (2008). Differentiation in the adolescent learner: Accommodating brian development, language, literacy, and special needs. Thousand Oaks: Corwin Press.

Dorn, L. D., Susman, E., \& Ponirakis, A. (2003). Pubertal timing and adolescent adjustment and behavior: Conclusions vary by rater. Journal of Youth and Adolescence, $32.3 \mathrm{p}$. $157-167$.

Ecuador, Ministerio de Educación del. (2011). Curriculum . Retrieved from www.educacion.gob.ec: http://educacion.gob.ec/objetivos-2/

King, K. M., Lengua, L. J., \& Monahan, k. C. (2013). Individual differences in the development of self-regulation during pre-adolescence: Connections to context and adjustment. Journal of Abnormal Child Psychology, 41.1 p. 57-69.

Lerner, R. M. (2002). Adolescence development, diversity, context, and application. Upper Saddle River: Prentice Hall.

Oberle, E., chonert-Reichl, K. A., \& Thomson, K. C. (2010). Understanding he link between social and emotional well-being and peer relations in early adolescence: Genderspecific predictors of peer. Journal of Youth and Adolescence, 39.11 p. 1330-42.

Osguthorpe, R. D. (2009). On the possible forms a relationship might take between the moral character of a teacher and the moral development of a student. Teachers College Record, 111 (1) p. 1-26.

Queen, J. A. (2002). Student transitions from middle to high school. Larchmont: Eye on Education.

Sund, A. M., Larsson, B., \& Wichstrom, L. (2011). Role of physical and sedentary activities in the development of depressive symmtoms in early adolescence. Social Psychiatry and Psychiatric Epidemiology, 46.5 p. 431-41.

Sylwester, R. (2007). The adolescent brain: Reaching for autonomy. Thousand Oaks: Corwin Press. 
Williams, J. M., \& Currie, C. (2000). Self-esteem and physical development in early adolescence: Pubertal timing and body image. The Journal of Early Adolescence, 20.2 p. $129-149$.

\section{PARA CITAR EL ARTÍCULO INDEXADO.}

Cárdenas Sánchez, S., Morales Rodas, L., \& Goyes Robalino, A. (2019). Teaching English as a foreign language to young adolescents. Ciencia Digital,3(3.1), 91-101. https://doi.org/10.33262/cienciadigital.v3i3.1.678

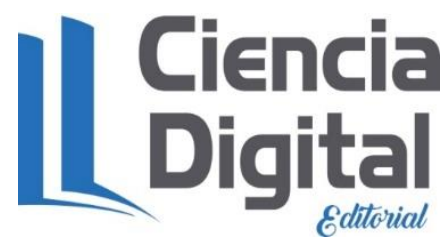

El artículo que se publica es de exclusiva responsabilidad de los autores y no necesariamente reflejan el pensamiento de la Revista Ciencia Digital.

El artículo queda en propiedad de la revista y, por tanto, su publicación parcial y/o total en otro medio tiene que ser autorizado por el director de la Revista Ciencia Digital.
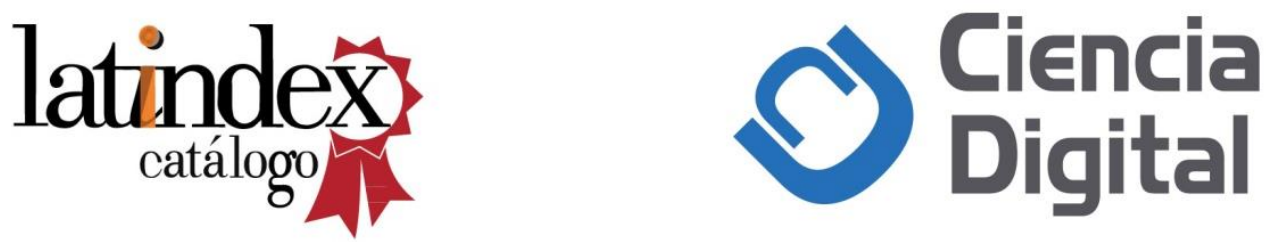